\title{
Subgross and macroscopic investigation of the coeliac artery in the chinchilla (chinchilla lanigera)
}

\author{
V. Özdemir, A. Çevik Demirkan, M.S. Akosman \\ Department of Anatomy, Faculty of Veterinary Medicine, ANS Campus, Afyon Kocatepe University, Afyonkarahisar, Turkey
}

[Received 11 March 2013; Accepted 18 April 2013]

\begin{abstract}
The knowledge of branching and variations of the coeliac artery is clinically important, especially in the surgical operations and non-surgical treatments. Moreover, the chinchillas abdominal region have been used as a model in some surgical experimental researches. In this frame, we have aimed to explain the branching of this artery in the chinchillas detailedly. A total of 10 adult, healthy, male chinchillas (chinchilla lanigera) were used to investigate the origin and the course of the coeliac artery and its branches. Coloured latex was injected into the carotid arteries, following conventional anatomical applications. The results indicated that the coeliac artery was divided into 4 branches such as left gastric artery, hepatic artery, splenic artery and gastrolienal artery. The left gastric artery was a continuity of the coeliac artery and the main vessel of the stomach. The hepatic artery was divided into the left lateral branch, the left medial branch and the right branch. The splenic artery was covered by the pancreas tissue and sent branches to the pancreas. The gastrolienal artery was supplying the fundus of the stomach and the dorsal extremity of the spleen. We believe that the findings will be of help to the researchers interested in the anatomical area, surgeons and experimental researches. (Folia Morphol 2013; 72, 3: 258-262)
\end{abstract}

Key words: aorta abdominalis, coeliac artery, chinchilla

\section{INTRODUCTION}

The chinchilla is best known for its incredibly soft, thick and luxurious fur. Recently, it has also become a very popular pet animal around the world [9]. It belongs to the Chinchillidae [9, 14] family of the Rodentia, order in Mammalia, and was originated from South American countries, i.e. Chile, Peru, and Bolivia [21]. It is also gross anatomically closely related in many ways to the porcupine and the guinea pig [21].

Recently, the chinchillas have been used in some experimental researches for the surgical, toxicological and pharmacological experiments $[7,10,12,13,20]$.
Due to that fact, it would be beneficial to perform more detailed investigations on the vascularisation of their internal organs. A number of studies have been conducted on the coeliac artery ( $A$. celiaca) or its branches in several animals, including rabbit $[3,8,16]$, badger [22, 26], muskrat [6], porcupine [2], sheep, goat, and ox [11, 18], and guinea pig [4]. Studies into the coeliac artery and its branches of the chinchilla appear to be scarce, thus this paper aims to reveal the conformation and ramification of the coeliac artery in the chinchilla, provide information enhancing current understanding and contribute to the surgery department. 


\section{MATERIALS AND METHODS}

Ten adult, healthy, male chinchillas (1-1.5 years old, 450-500 g), obtained from the Faculty of Veterinary Medicine, Afyon Kocatepe University, Afyonkarahisar, Turkey, were anaesthetised with the combination of $1 \mathrm{mg} / \mathrm{kg}$ xylazine (Rompun ${ }^{\circledR}$ enj, Bayer Turk Kimya San. Ltd. Sti. Istanbul) and $10 \mathrm{mg} / \mathrm{kg}$ ketamine $\mathrm{HCl}$ (Ketalar ${ }^{\circledR}$ Eczacıbaşı, Istanbul). Heparin (Liquemine IV, Roche Mustahzarları San. A.S.) was administered to prevent the coagulation. Later, the animals were bled by means of an incision to the carotid arteries, the vessels were washed with $0.9 \%$ physiological saline, and red coloured latex was injected into the carotid arteries. After polymerisation at room temperature, the coeliac artery was observed grossly and by using a dissection microscope (Nikon SMZ-2T, Nikon Corp., Tokyo, Japan). The findings were recorded and photographed (Sony DSC F 717, Sony Corp., Tokyo, Japan). Anatomical nomenclature of the coeliac artery was named in accordance with N.A.V. [19].

\section{RESULTS}

The coeliac artery was the first visceral branch of the abdominal aorta (Aorta abdominalis) and left from the ventral wall of the parent vessel. After its origin, the vessel coursed ventrally, approximately $12 \mathrm{~mm}$, and then separated into 4 main branches, called as the left gastric artery ( $A$. gastrica sinistra), hepatic artery ( $A$. hepatica), splenic artery $(A$. lienalis) and gastrolienal artery ( $A$. gastrolienalis), which supplies fundus of the stomach and dorsal extremity of the spleen. These vessels arose at the same level from the coeliac artery (Fig. 1). The left gastric artery represented the continuation of the coeliac artery.

The left gastric artery (Figs. 1e, 2e) was the thickest one from the branches of the coeliac artery. It was the principal artery of the stomach. After its origin, the vessel continued to the lesser curvature of the stomach. On reaching the cardia, the left gastric artery gave off its 2 terminal branches, the parietal branch (ramus parietalis) (Fig. 1n) and the visceral branch (ramus visceralis) (Fig. 1h). The parietal branch was passed to the parietal surface of the stomach. On its course a thin branch was left from this vessel to the lesser curvature. Just after reaching the parietal surface of the stomach, the parietal branch sent the oesophageal branches (rami esophagei) (Fig. $2 \mathrm{~g}$ ) to the terminal part of the oesophagus. In 1 chinchilla, the oesophageal branches arose from the left gastric artery. After the origin of the oesophageal branches,

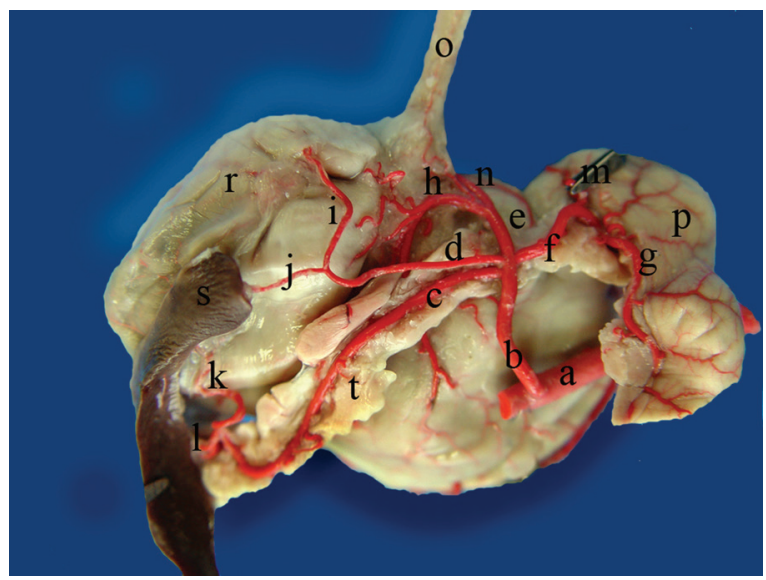

Figure 1. Ramification of the coeliac artery; a - aorta abdominalis; $b$ - arteria celiaca; c - arteria lienalis; $d$ - arteria gastrolienalis; e - arteria gastrica sinistra; $f$ - arteria hepatica; $\mathrm{g}$ - arteria gastroduodenalis; $\mathrm{h}$ - ramus visceralis of the left gastric artery; $i$ and $j-$ ventricular and splenic branches of the arteria gastrolienalis; $\mathrm{k}$ - arteria gastroepiploica sinistra; $\mathrm{I}$ - splenic branches of the arteria lienalis; $\mathrm{m}$ - origin point of the arteria hepatica; $\mathrm{n}$ - ramus parietalis of the arteria gastrica sinistra; 0 - oesophagus; $\mathrm{p}$ - pyloris; $\mathrm{r}$ - fundus ventriculi; $\mathrm{s}$ - extremitas dorsalis of the spleen; $\mathrm{t}$ - pancreas.

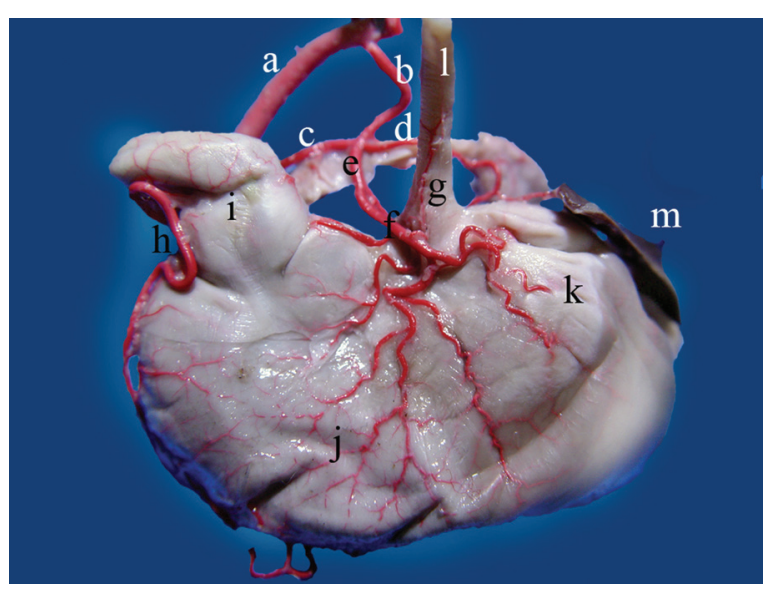

Figure 2. Parietal surface of the stomach; a - aorta abdominalis; b - arteria celiaca; c - arteria hepatica; $d$ - arteria gastrolienalis; $\mathrm{e}$ - arteria gastrica sinistra; $\mathrm{f}$ - ramus parietalis of the arteria gastrica sinistra; $\mathrm{g}$ - rami esophagei; $\mathrm{h}$ — arteria gastroepiploica dextra; $\mathrm{i}$ - pyloris; $\mathrm{j}$ - corpus ventriculi; $\mathrm{k}$ - fundus ventriculi; I — oesophagus; $\mathrm{m}$ — lien.

the parietal branch of the left gastric artery was divided into 3 branches, the first one coursed to the fundus of the stomach, the second branch dispersed on the body of the stomach and the last one reached the pyloric part of the stomach. The visceral branch of the left gastric artery (Figs. 1h, 3e), after reaching the visceral surface of the stomach, continued to the greater curvature of the stomach and in its course the 


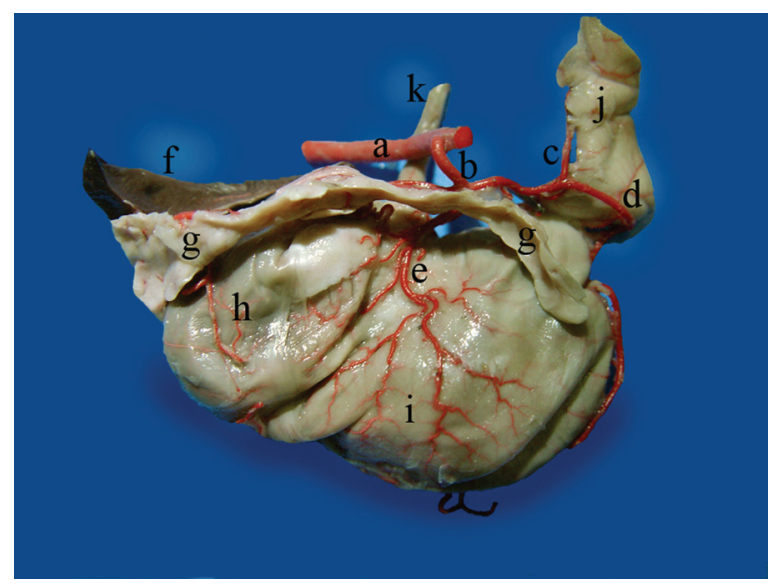

Figure 3. Visceral surface of the stomach; a — aorta abdominalis; $\mathrm{b}$ - arteria celiaca; c — arteria gastroduodenalis; $\mathrm{d}$ - arteria gastroepiploica dextra; $\mathrm{e}$ - visceral branch of the arteria gastrica sinistra; $\mathrm{f}$ - lien; $\mathrm{g}$ - pancreas; $\mathrm{h}$ - fundus ventriculi; $\mathrm{i}$ - corpus ventriculi; $\mathrm{j}$ - duodenum; $\mathrm{k}$ - oesophagus.

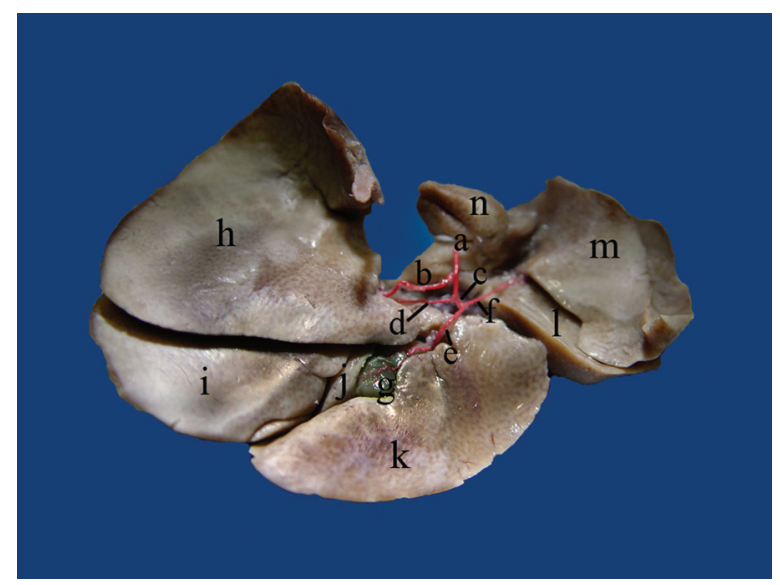

Figure 4. Ramification of the hepatic artery; $a$ - hepatica; $b$ ramus sinister lateralis; $\mathrm{c}$ - ramus dexter; $\mathrm{d}$ - ramus sinister medialis; $\mathrm{e}$ - ramus dexter medialis; $\mathrm{f}$ - ramus dexter lateralis; $\mathrm{g}$ - vesica fella; $\mathrm{h}$ - lobus hepatis sinister lateralis; $\mathrm{i}$ - lobus hepatis sinister medialis; $\mathrm{j}$ - lobus quadratus; $\mathrm{k}$ - lobus hepatis dexter madialis; I - lobus hepatis dexter lateralis; $m$ - lobus caudatus; $\mathrm{n}$ - processus papillaris.

vessel gave off many branches to the visceral surface of the stomach.

The hepatic artery (Figs. 1f, 2c, 4a), after its origin, continued to the liver and after $3 \mathrm{~mm}$ of starting point, the cranial pancreaticoduodenal artery (A. pancreaticoduodenalis cranialis) gave off to the right lobe of the pancreas. Nearly $4 \mathrm{~mm}$ from its origin, the hepatic artery left from parent vessel to reach the liver. Just after reaching the liver the hepatic artery gave off the left lateral branch (ramus sinister lateralis) (Fig. 4b) to the left lateral lobe (lobus hepatis sinister lateralis) of the liver. After occurring the left lateral branch, the hepatic artery gave off 2 branches that are named the left medial branch (ramus sinister medialis) and the right branch (ramus dexter). The left medial branch (Fig. 4d) dispersed to the left medial lobe of the liver (lobus hepatis sinister medialis) and quadrate lobe of the liver. The right branch (Fig. 4c) coursed to the right lobe of the liver and divided into 2 terminal branches named the right lateral branch (ramus dexter lateralis) and the right medial branch (ramus dexter medialis). The right lateral branch (Fig. 4f), after its origin, coursed to the right lateral lobe of the liver (lobus hepatis dexter lateralis) and gave off the branch to the caudate lobe (a. lobi caudati). The right medial branch (Fig. 4e) was thicker than the right lateral branch and this vessel was supplying the right medial lobe of the liver (lobus hepatis dexter medialis). In its course, this vessel gave off the cystic artery (A. cystica) to the gall bladder.

After leaving the hepatic artery, the main vessel continued being right gastric artery ( $A$. gastrica dexter) and reached pyloric part of the stomach. At this point a thin branch left from the right gastric artery to feed the pyloric part of the stomach in 6 chinchillas. After originating of this branch, the right gastric artery divided into 2 terminal branches: the gastroduodenal artery ( $A$. gastoduodenalis) and the right gastroepiploic artery (A. gastroepiploica dexter). The gastroduodenal artery (Figs. 1g, 3c) gave off branches to the pyloric region of the stomach and continued to the duodenal bulb. The right gastroepiploic artery (Figs. 2h, 3d) reached greater curvature of the stomach at the level of the pyloric region of the stomach and coursed along the greater curvature. Terminal branches of this artery were anastomoses, with branches of left gastroepiploic artery (A. gastroepiploica sinistra) on the left part of the greater curvature of the stomach.

The splenic artery (Fig. 1c), after $2 \mathrm{~mm}$ from the origin, entered into the pancreas tissue. On its way to the spleen, covered by the pancreas, the splenic artery gave off small pancreatic branches to the body and left lobe of the pancreas, named as pancreatic branches (rami pancreatici). After reaching the hilar region (hilus lienalis), the splenic artery sent 2-3 branches to the body and ventral extremity of the spleen (Fig. 1I). Then, it continued being left gastroepiploic artery 
(Fig. 1k) and coursed to the curvatura ventriculi major of the stomach. Along its course, the vessel sent 2-3 small branches to the stomach (Aa. gastricae breves). The left gastroepiploic artery ended at the last part of the fundus of the stomach by anastomosing with the right gastroepiploic artery of the gastroduodenal artery, which arose from the hepatic artery.

The gastrolienal artery (Figs. 1d, 2d), arose from the coeliac artery, was found in the chinchillas. This artery, after its origin, coursed to the left side of the stomach and at the level of the fundus of the stomach divided into 2 terminal branches. One of the branches reached the dorsal extremity of the spleen (Fig. 1j) and the other one coursed to the greater curvature of the stomach, supplying the fundus of the stomach (Fig. 1i).

\section{DISCUSSION}

In the chinchillas, the coeliac artery originated from the abdominal aorta as an independent trunk, like as carnivores [11, 18], beaver [5], badger [22, 26], muskrat [6], wood mouse [15], and rabbit [3, 8, 16].

It was reported that the coeliac artery separates into 3 branches in the carnivores [11, 18], rabbit $[3,8]$ and badger $[22,26]$ as the left gastric artery, hepatic artery and splenic artery. On the other hand, in porcupines [2], rats [24], and pigs [11], the coeliac artery was reported to separate into 2 branches splenic artery and hepatic artery, while Lopez-Fuster and Ventura [15] called them as splenic artery and gastrohepatic trunk in the wood mause. In the chinchillas, as have been observed in the present study, the coeliac artery separated into 4 branches and gastrolienal artery was seen in addition to other 3 vessels. Yılmaz et al. [26] reported that the splenic artery was the continuance of the coeliac in badger. On the other hand, Atalar and Yılmaz [2] stated that the hepatic artery was the continuity of the coeliac artery in porcupine. In the present study, it have been observed that the left gastric artery was the continuity of the coeliac artery.

While it was reported that the left gastric artery arises from the splenic arterty in pigs [18] and from the hepatic artery in porcupines [2], we have observed in the present study, that the left gastric artery originated from coeliac artery similarly to muskrats [6], badgers [26], rabbits [3, 8], and rats [24]. It was observed that in the chinchillas, the oesophagial branches left from the left gastric artery as in carnivores [11, 18], badgers [26], and muskrats [6], while
Atalar and Yılmaz [2] stated that this vessel was not observed in the porcupines. It was reported that the cardiac artery was found, supplying the cardia of the stomach, which left from the left gastric artery in the muskrats [6]. The cardiac part of the stomach was supplied by the branches of visceral, parietal and terminal branches of the gastric artery in the chinchillas, as in badgers [26] and porcupines [2].

It was reported that the cranial pancreaticoduodenal artery is a branch of the gastroduodenal artery in the muskrats [6], guinea pigs [4], porcupines [2], badgers [26] and carnivores [11, 18], but in the chinchillas, this vessel arose from the hepatic artery directly. The hepatic artery was reported to divide into the left, right medial and right lateral branches in badgers [26], while the left and right branches were reported in the porcupines [2]. In our study we have observed that the hepatic artery divided into the left lateral, left medial and right branches in the chinchillas. According to the authors, the cystic artery arose from the proprial hepatic artery (A. hepatica propria) in guinea pigs [4], from the right branch in porcupines [2], and from the right medial branch in badgers [26]. In chinchillas the cystic artery was a branch of the right medial branch, like in badgers.

In our study, the splenic artery was observed to be covered by the pancreas tissue, just after its origin, and coursed to the spleen in this status. Similar finding were not reported in any animals.

While it was reported that the spleen is supplied by the branches of the splenic artery in the guinea pigs [4], porcupines [2], badgers [26], and carnivores $[11,18]$, in the present study we have observed that there was a branch, in addition to the splenic artery, coming from the gastrolienal artery which was a vessel arisen from the coeliac artery. This branch supplied the dorsal extremity of the spleen.

The gastrolienal artery was reported to exist in the Mediterranean pine voles [25], porcupines [2], guinea pigs [4], and pigs [11]. This vessel was reported to arise from the splenic artery in porcupines [2]. In our study this vessel existed and left from the coeliac artery directly as in the Mediterranean pine voles [25]. Atalar and Yilmaz [2] stated that the splenic branch of the gastrolienal artery was dispersed to the hilar region of the spleen in porcupines, but in the chinchillas this splenic branch was supplying only dorsal extremity of the spleen.

Generally, the classical branching of the coeliac artery is noticed in the dogs, but in 1 case the 
coeliac artery sent a branch to the caudal lobe of the right lung [23]. The scientists mentioned the importance of the vessel variations $[1,17,23]$. The variation generally does not affect the functions of the body, but besides the anatomical and embryological fields it is of clinical importance during the surgical or non-surgical treatments [23].

\section{CONCLUSIONS}

In conclusion, the coeliac artery and its branches were examined in this study. The variations and the differences were detected and presented. The vessels originating from the coeliac artery displayed some significant differences in chinchillas compared to rats, guinea pigs, rabbits, porcupines and other laboratory rodents. The results of the present study may contribute to the extension of data in this field of science and experimental researches and also broaden the knowledge of the surgeons.

\section{REFERENCES}

1. Abidu-Figueiredo $M$, Xavier-Silva B, Cardinot TM, Babinski MA, Chagas MA (2008) Celiac artery in New Zealand rabbit: anatomical study of its origin and arrangement for experimental research and surgical practice. Pesq Vet Bras, 28: 237-240.

2. Atalar O, Yilmaz S (2004) The branches of the arteria celiac in the porcupine (Hystrix cristata). Vet Med Czech, 49: 52-56.

3. Barone R (1973) Atlas of rabbit anatomy. Masson and C Editeurs, Boulevard Saint-Germain, Paris.

4. Bednarova Z, Malinovsky L (1990) Variability of branching of the a. coeliaca (truncus coeliacomesentericus) in the guinea pig (Cavia aperea f. porcellus). Folia Morphol, 38: 382-395.

5. Bisaillon A, Bherer J (1979) Gross anatomy of the arterial supply of the stomach of the North American beaver (Castor canadensis). Acta Anat, 104: 79-85.

6. Bisaillon A, Grenier A, Bousquet R (1988) Arterial blood supply to the stomach of the muskrat (Ondatra zibethicus). Anat Histol Embryol, 17: 7-11.

7. Conze J, Rosch R, Klinge U, Weiss C, Anurov M, Titkowa S, Oettinger A, Schumpelick V (2004) Polypropylene in the intra-abdominal position: influence of pore size and surface area. Hernia, 8: 365-372.

8. Craigie EH (1969) Bensley's practical anatomy of the rabbit. Universty of Toronto press, Toronto.
9. Erençin Z (1977) Prey animals and hunt. Ank. Üniv. Vet. Fak. Yayınları, Ankara.

10. Ewuola EO (2009) Organ traits and histopathology of rabbits fed varied levels of dietary fumonisin $B(1)$. J Anim Physiol Anim Nutr, 93: 726-731.

11. Getty R (1975) Sisson and Grossman's the anatomy of the domestic animals. W.B. Saunders Company, Philedelphia.

12. Klimtová I, Simůnek T, Mazurová Y, Hrdina R, GersI V, Adamcová $\mathrm{M}$ (2002) Comparative study of chronic toxic effects of daunorubicin and doxorubicin in rabbits. Hum Exp Toxicol, 21: 649-657.

13. Kozlov $Y$, Novogilov V, Rasputin A, Podkamenev A, Krasnov P, Weber I, Solovjev A (2012) Laparoscopic inguinal preperitoneal injection: novel technique for inguinal hernia repair: preliminary results of experimental study. J Laparoendosc Adv Surg Tech A, 22: 276-279.

14. Kürschner M (1992) Unser Chinchilla. Franckh-kosmos, Verlags-Gmbh Co., Stuttgart.

15. Lopez-Fuster MJ, Ventura J (1992) Arrangement of the branches of the aorta abdominalis in the wood mause (Apodemus sylvaticus). Anat Histol Embryol, 21: 146-151.

16. McLaughlin CA, Chiasson RB (1990) Laboratory anatomy of the rabbit. WMC, Brown Company, USA.

17. Nayak SR, Prabhu LV, Krishnamurthy A, Kumar CG, Ramanathan LA, Acharya A, Sinha AP (2008) Additional branches of celiac trunk and its clinical significance. Romanian J Morphol Embryol, 49: 247-249.

18. Nickel R, Schummer A, Seiferle E (1981) The Anatomy of the domestic animals. Verlag Paul Parey, Berlin.

19. Nomina Anatomica Veterinaria (NAV) (2012) International Committee on Veterinary Gross Anatomical Nomenclature, Ithaca, World Association of Veterinary Anatomists.

20. Otto J, Kämmer D, Jansen PL, Anurov M, Titkova S, Ottinger A, Rosch R, Schumpelick V, Jansen M (2008) Different tissue reaction of oesophagus and diaphragm after mesh hiatoplasty. Results of an animal study. BMC Surg, 12: 8-7.

21. Poyraz Ö (2000) Laboratory Animal Science. Kardelen ofset, Ankara.

22. Rahm S, Frewein J (1982) Arterial Blood Supply of the digestive tract in badgers. Acta Anat, 113: 202-210.

23. Roza MS, Marinho GC, Pereira JA, Salvador-Gomes M, Abidu-Figueiredo M (2012) Celiac artery with pulmonary branch in dog: a rare variation. J Morphol Sci, 29: 253-255.

24. Walker WF, Homberger DG (1998) Anatomy and dissection of the rat. W.H. Freeman and Company, England.

25. Ventura J, Lopez-Fuster MJ, Gispert E (1995) Blood supply to the Abdominal and pelvic regions in the Mediterranean pine vole, Microtus duodecimcostatus (Rodentia, Arvicolidea). Anat Histol Embryol, 24: 133-137.

26. Yilmaz S, Atalar Ö, Aydin A (2004) The branches of the arteria celiac in badger. Ind Vet J, 81: 183-187. 